\title{
SÎN-LĒQI-UNNINNI, ELE O ABISMO VIU (SÉRIE DE GILGÁMESH 1)
}

\author{
Jacyntho Lins Brandão* \\ Universidade Federal de Minas Gerais
}

\begin{abstract}
RÉSUMÉ: Je présente ici une traduction commentée de la première tablette du poème babylonien sur Gilgamesh attribué à Sîn-lēqiunninni, Sha naqba imuru (Il a vu l'abîme).

MOTS-CLÉS: Epopée de Gilgamesh; Poésie acadienne; Littérature babylonienne.
\end{abstract}

presento a tradução da primeira tabuinha de Ele o abismo viu (Sha naqba imuru), poema babilônico que se costuma intitular "Epopeia de Gilgámesh". Trata-se do primeiro resultado que publico de projeto em fase de finalização e que teve como objetivo traduzir todo o poema diretamente do acádio. ${ }^{1}$

Esta não constitui a primeira tradução para o português, pois contamos com o livro de Ordep Trindade Serra, A mais antiga epopeia do mundo: a gesta de Gilgamesh, publicado pela Fundação Cultural do Estado da Bahia, em 1985, trabalho de excelente qualidade e atualizado com relação à época em que foi escrito. $\mathrm{O}$ aparecimento da edição crítica de Andrew R. George, The Babylonian Gilgamesh Epic: introduction, critical edition and cuneiform texts (Oxford: Oxford University Press, 2003), marca, contudo, uma nova etapa para o conhecimento do poema, impondo por igual novos esforços de tradução. O texto crítico de George substitui as edições anteriores, em especial a de R. Campbell Thompson, publicada ainda em 1930, primando pelo detalhe, pela exatidão e pelo domínio dos métodos críticos em todas as suas dimensões. Acrescente-se que foram compulsados

^e-mail: jlinsbrandao@ufmg.br

${ }^{1}$ Projeto beneficiado com Bolsa de Produtividade em Pesquisa do Conselho Nacional de Desenvolvimento Científico e Tecnológico, CNPq. 
por ele todos os manuscritos descobertos ou disponibilizados depois de 1930, o que provê um considerável volume de leituras e informações novas.

Esta é uma das razões de minha tradução, o dispormos agora de um novo texto crítico, o que exige, em certo sentido, que todas as traduções sejam refeitas, a outra, dela decorrente, sendo a possibilidade de traduzir não um apanhado de textos distintos muitíssimo fragmentados a fim de apresentar um fio narrativo mínimo, como se fez no passado, mas um poema inteiro, o que se intitula Ele o abismo viu, de que conhecemos inclusive o "autor", Sîn-lēqi-unninni.

Evidentemente se deve falar de autoria com todas as precauções necessárias quando lidamos com o mundo antigo, da mesma forma, por exemplo, como devemos nos precaver ao afirmar que Homero é o "autor" da Ilíada. Todavia, se há uma grande possibilidade de que este que se chamou de Homero fosse antes um "aedo", tendo em vista as peculiaridades de composição oral dos poemas (o elemento cujo conhecimento seria mais empolgante escapando-nos definitivamente: a passagem do oral para o escrito), no caso de Sîn-lēqi-unninni temos uma certeza: trata-se de um escriba. A versão da "gesta" de Gilgámesh que a ele se deve, como acontece com relação a ciclos poéticos semelhantes, não constitui uma obra "original" (no sentido moderno), pois trabalha ele com uma tradição escrita em sumério e acádio que já contava, em sua época, com mais de meio milênio. Portanto, é lidando com essa tradição escrita que Sîn-lēqi-unninni, ele próprio um escriba, compõe a nova versão do poema, entre os séculos XII e XI a.C., trabalho destinado a tornar-se a versão clássica (ou, como preferem os autores ingleses, standard) da épica sobre Gilgámesh. Nela, a mão do "poeta" deixa-se perceber sobretudo pela profundidade que imprime à antiga saga, ao trazer para primeiro plano a pergunta sobre a mortalidade do homem, que transforma o seu herói, de simples aventureiro, num verdadeiro sábio.

A tradução que ofereço pretende-se bastante próxima do original babilônico, observando as convenções poéticas dele próprias. Registre-se que a poesia acádia, como a de outras línguas semíticas antigas, não tem como base algum esquema métrico fixo, mas constrói um ritmo baseado em unidades sintáticas, um verso comportando, em geral, duas dessas unidades. Além disso, pode-se dizer que, dentre outros recursos poéticos, os mais relevantes são os de natureza paralelística, envolvendo expressões, versos, trechos e mesmo falas e cenas inteiras, o que também marca, no seu nível, o ritmo do texto. Assim, não sendo esta uma tradução poética, tem, contudo, a pretensão de não tolher a percepção dos torneios que garantem ao leitor ser um poema o que ele tem sob os olhos.

Essa pretensão se desdobra e completa nos comentários, que abrangem também outros problemas e aspectos do poema. Trata-se de 
uma parte que efetivamente integra o trabalho (por isso insisto: não foram escritos como notas de pé de página, mas como comentários de pleno direito), de tal modo que eu poderia definir o que se publica como uma "tradução comentada". Essa definição tanto orientou minha maneira de traduzir, quanto a própria apresentação do texto. No meu modo de entender, tradução comentada é aquela que termina por deixar expostas as dificuldades enfrentadas pelo tradutor, tanto no que diz respeito à decifração do texto, quanto às opções assumidas ao vertê-lo, com base em critérios de relevância. Isso, naturalmente, supõe entrar em diálogo com a fortuna crítica, bem como com as soluções encontradas por outros tradutores, o que tem como consequência abrir a possibilidade de expansão do diálogo com o leitor.

Por fim, dois alertas aos leitores se fazem necessários: a) a fim de deixar marcadas de um modo mais claro as sequências da narrativa, acrescentei títulos às mesmas (títulos que naturalmente não se encontram no original); b) com relação aos nomes próprios que aparecem no texto, acentuei a sílaba que, de acordo com o que se sabe relativamente à língua da época em que o poema foi escrito, deveria ser a tônica, assim, Gilgámesh, Enkídu, mas fiz isso considerando as normas de acentuação do português, o que faz com que Ninurta, por exemplo, sendo um paroxítono terminado em -a, não necessite de acento algum.

\section{Sîn-lēqi-unninni* \\ ELE O ABISMO VIU* \\ (Série de Gilgámesh) ${ }^{*}$}

\section{COMENTÁRIOS}

[Autor] A atribuição do texto a Sin-léqi-unnínni (Sîn-lēqi-unninni) encontrase em catálogo redigido no primeiro terço do primeiro milênio a.C. e achado em Nínive, no qual se lê: "Série de Gilgámesh (iškar Gilgāmeš): da boca (ša pî) de Sîn-lēqi-unninni, [sacerdote-exorcista]”. A última qualificação é de leitura duvidosa, já que depende de conjetura, tendo sido proposto que se lesse, em vez de "exorcista", "mago" ou "adivinho".

A expressão "da boca de..." é um modo de indicar aquele a quem se deve a versão em causa, equivalendo a "segundo..." Mesmo que a noção de autor não corresponda exatamente à nossa, admite-se que Sin-léqi-unnínni tenha composto a versão clássica do poema por volta dos séculos XII-XI antes de nossa era, remanejando relatos anteriores. Parece que é a ele que se deve o tratamento grandioso da saga de Gilgámesh, centrado na questão da mortalidade do homem (cf. Lambert, 1962, p. 28, nota 74; SEG, p. 58-59). 


\section{TABUINHA 1}

\section{Proêmio}

[1] Ele o abismo viu, o fundamento da terra,

Ele - - - conheceu, ele sabedor de tudo,

Entretanto, note-se que Sin-léqi-unnínni é reivindicado como ancestral por muitos escribas de Úruk, ou seja, trata-se do epônimo de toda uma categoria de intelectuais, num processo semelhante ao que se dá com os Homeridas e Homero, na Grécia (cf. Spar e Lambert, 2005, p. XVII; Lambert, 1957, p. 13).

[Título] É usual na tradição médio-oriental que as obras sejam conhecidas a partir de suas primeiras palavras, como, neste caso: ša naqba imuru (literalmente, "aquele que o abismo viu”).

[Série] Série de Gilgámesh (iškar Gilgāmeš) é como era também conhecida, nos catálogos das bibliotecas, a sucessão de onze ou doze tabuinhas do poema. O termo iškaru $(m)$ apresenta esse uso especializado, como em iškar Etana (série de Etana), iškar mašmaššūti (série de encantamentos) etc.

[Versos 1-62] A parte inicial do poema constitui uma espécie de hino dedicado a enaltecer Gilgámesh. Parece que Sîn-lēqi-unninni incorporou a ela a abertura da versão babilônica antiga, intitulada "Proeminente entre os reis" (šutur eli šarri), expressão que ocorre no v. 29. Assim, pode-se considerar que o proêmio divide-se em duas partes: a primeira louva os trabalhos (no sentido de feitos e de sofrimentos) do herói (v. 1-28); a segunda concentra-se em sua origem divina, seu talhe portentoso e sua beleza (v. 29-62).

[Verso 1] As primeiras palavras do poema, ša naqba imuru, poderiam ser vertidas de duas formas: "o que tudo viu" e "o que o abismo viu". O termo naqbu pode ter dois sentidos, a saber: a) uma fonte ou, de modo especial, o abismo subterrâneo de águas que se acredita que alimenta as fontes, ou seja, o reino cósmico de Ea conhecido como Apsî; b) em uso poético, uma totalidade (cf. CAD, s.v.; GBGE, p. 444-445). Minha opção pela segunda alternativa leva em conta as razões apresentadas por Silva Castillo (1998, p. 219-221 e 2000).

Para a tradução do segundo hemistíquio (ǐsdi mati) como "o fundamento da terra", baseio-me também em Silva Castillo, 2001. 
[3] Gilgámesh o abismo viu, o fundamento da terra,

Ele - - - - conheceu, ele sabedor de tudo.

[5] Ele - - - - da mesma maneira,

De todo saber, tudo aprendeu, ${ }^{\star}$

[7] O que é secreto ele viu, e o coberto descobriu,

Trouxe isto e ensinou, o que antes do dilúvio era.

[9] De distante caminho volveu, cansado e pacificado, * .

Numa estela pôs então o seu labor por inteiro.

[Verso 6] A expressão do primeiro hemistíquio é naphar nēmeqi, literalmente "a totalidade do saber", nēmequ $(m)$ significando "sabedoria", "sagacidade", "conhecimento civilizado", "habilidade". Trata-se, portanto, de uma sabedoria prática, decorrente dos próprios feitos heroicos.

[Verso 8] A tradição relativa ao dilúvio (abūbum) é bastante característica da Mesopotâmia (ver d'Agostino, 2007, p. 169-185). Na produção acádia, o relato clássico do cataclismo encontra-se no poema antropogônico intitulado Atra-hasīs (Supersábio), cujo manuscrito mais antigo é assinado pelo copista Kasap-Aya, que executou o trabalho sob o reinado de Amim-șadûqa (1646-1626 a.C.), cf. Bottéro e Kramer, 1993, p. 528-529. Parece que Sin-léqi-unnínni se valeu desse texto na tabuinha XI, pondo o relato na boca de Uta-napíshti (Ūta-napišti). Todavia, Silva Castillo, 2000, p. 14, considera o episódio do dilúvio uma "interpolação tardia".

[Verso 9] A referência é à grande viagem empreendida por Gilgámesh após a morte de seu companheiro de feitos heroicos, Enkídu. A pergunta que imprime profundidade à saga do herói na versão de Sin-léqi-unninni diz respeito ao impasse diante da morte, razão pela qual o herói empreende o longo percurso por espaços não-humanos, em busca da imortalidade.

[Verso 10] Era costume dos reis registrar numa estela (narû) algum acontecimento importante de seu reinado, visando a torná-lo público. Um narû pode ter ainda o valor de documento jurídico, pode marcar uma fronteira ou ser a "pedra fundamental" (feita realmente de pedra ou então de prata, ouro ou bronze) de um templo, enterrada nas fundações ou posta em seu interior (cf. SEG, p. 109). Considerando-se o que se diz nos v. 24-28, que marcam o fim da introdução ao poema, parece que se quer dar a entender que se trata da última hipótese. Cumpre, todavia, recordar que, longe de pretender um valor documental, a referência à inscrição constitui um recurso poético que provavelmente deveria ser percebido enquanto tal pelo leitor (ou ouvinte) do poema (cf. Oppenheim, 1977, p. 258, apud Dickson, 2009, p. 27), ao qual o texto passa a dirigir-se explicitamente dois versos adiante. 
[11] Fez a muralha de Úruk, o redil,

E o sagrado Eanna, tesouro purificado.

[13] Vê sua base: é como um fio de lã,

Olha seus parapeitos que ninguém igualará.

[Verso 11] O epíteto tradicional de Úruk é supūru(m), ou seja, "curral", "redil". A cidade era rodeada por uma muralha circular de cerca de nove quilômetros de extensão, que parece datar da época pré-dinástica. O interior nunca foi inteiramente ocupado com edificações, o que tornava possível que nele existissem currais para o gado, usados especialmente quando se tratava de protegê-lo de ataques externos (cf. 22-23). A muralha, conforme o poema, era obra de Gilgámesh.

[Verso 12] O e-anna, literalmente "casa de Ánu" (Ánu é a divindade que se identifica como o Céu), compreendia o templo desse deus e o de Ishtar, além de outros, possuindo uma ziqqurat (torre escalonada) típica dos santuários mesopotâmicos.

[Versos 13-28] Inicia aqui a sequência, que se estende até o v. 28, dominada pelos imperativos dirigidos ao leitor (ou ouvinte) do poema. São dois os elementos principais: aquele com o qual ela se abre, os muros de Úruk, obra de Gilgámesh (v. 13-23); e a tabuinha de lápis-lazúli em que o próprio Gilgámesh escreveu os seus trabalhos, com que se encerra (v. 24-28). Em ambos os casos trata-se de grandiosas realizações, devendo ser salientado que os muros tiveram seus fundamentos lançados pelos sete heróis fundadores (os apkallū referidos no v. 21).

Conforme Dickson, 2009, p. 25, “as ações que o prólogo me convida a fazer são estruturadas por uma espécie de imitatio implícita (...). Exatamente como Gilgámesh 'viu o abismo', sou convidado a 'ver a muralha' de Úruk e 'olhar seu parapeito' (...), 'examinar os alicerces, inspecionar a alvenaria'”; do mesmo modo, "a inscrição feita por Gilgámesh de seus trabalhos ecoa literalmente em minha recitação do texto gravado na tabuinha retirada do cofre de cedro" (cf. v. 27-28). Em suma, trata-se de um sofisticado recurso poético que tem como efeito engajar o recebedor no louvor de Gilgámesh, fazendo com que assuma o papel de testemunha.

Digno de nota é ainda que os v. 13-23 se repetem na tabuinha 11, o convite a que se examine a muralha de Úruk sendo dirigido pelo próprio Gilgámesh ao barqueiro Ur-shánabi (Ur-šanabi, v. 323-328). Trata-se da conclusão da volta do herói de sua longa viagem em busca da imortalidade (e também da conclusão do poema, a tabuinha 12 podendo ser um acréscimo posterior). É, portanto, o próprio convite do protagonista a uma das personagens do poema que o narrador dirige neste 
[15] Toma a escadaria, que há ali desde o início,

Aproxima-te do Eanna, residência de Ishtar,

O qual nem rei futuro nem homem algum igualará.

[18] Faze a volta, ao alto da muralha de Úruk vai,

Seu fundamento examina, os tijolos observa,

[20] Se seus tijolos não são cozidos,

Se seu alicerce não cimentaram os sete.

[22] Um shar é cidade, um shar é pomar, um shar são poços de argila, meio shar é a casa de Ishtar:

[23] Três sharu e meio, a extensão de Úruk. *

[24] Busca o cofre de cedro,

Rompe o ferrolho de bronze,

[26] Abre a tampa do tesouro,

Levanta a tabuinha lápis-lazúli, lê

O que Gilgámesh passou, todos os seus trabalhos.

ponto ao leitor, com duplo resultado: o efeito de espelhamento (Gilgámesh está para o narrador como Ur-shánabi para o leitor); o efeito da composição em anel (Ringkomposition), o poema fechando-se com palavras que remetem a seu início.

[Verso 13] SEG, p. 110, lê o texto como ša kima qê nēbh [ušu] e o traduz por "como uma corda é seu recinto", o que significaria que se trata de espaço perfeitamente reto. George adota a lição kima qê nipši, "como um tufo de lã", que é a que sigo, inclusive por ser a leitura mais difícil.

[Verso 21] De acordo com as tradições mesopotâmicas, numa época anterior ao dilúvio sete sábios (em acádio, apkallū) foram enviados pelos deuses para civilizar a humanidade. Eles são representados numa forma não de todo humana, em geral com cabeça de peixe (cf. GDS, p. 163-164).

[Versos 22-23] O šăr é uma unidade de medida neobabilônica equivalente a cerca de 2,5 quilômetros quadrados. Tendo em vista o sistema sexagesimal que era então utilizado, correspondia a 60 vezes 60 , o que indicava uma cifra muito alta em termos de espaço ou tempo (cf. adi šârr, "para sempre", "em todo lugar"). Menos que fornecer uma medida exata, a intenção dos versos é ressaltar a imensidão de Úruk.

[Versos 24-28] O que se dá a entender é que os feitos de Gilgámesh se conservaram inscritos numa estela (cf. v. 10), que agora se qualifica como de lápis-lazúli. A referência a um cofre como o lugar em que a tabuinha foi depositada sugere que o escrito foi posto provavelmente no interior de um templo. 


\section{Proeminente entre os reis}

[29] Proeminente entre os reis, herói de imponente físico,

Valente rebento de Úruk, touro selvagem indomável:

[31] Vai à frente, é o primeiro,

Atrás vai e protege os irmãos.

Note-se ainda a importância da escrita. Ainda que a saga de Gilgámesh possa ter sido elaborada, na origem, como tradição oral (como parece que dá a entender a versão babilônica antiga do poema), na fase em que se situa a versão clássica, constitui tradição transmitida por escrito havia já muitos séculos, mais ainda, que se quer apresentar enquanto tal (cf. Abusch, 2001, p. 618).

[Verso 29] As palavras do primeiro hemistíquio, "proeminente entre os reis" (šutur eli šarri), constituem o início e, consequentemente, o título da chamada "versão babilônica antiga" do poema de Gilgámesh, uma série, na forma como nos chegou, que parece contava com quatro tabuinhas (veja-se a tradução do poema em GBGE, p. 173-192; SEG, p. 334-342). Isso mostra como Sîn-lēqi-unninni utilizou textos anteriores na composição da versão clássica. Parece que se trata de um procedimento intertextual de que se lança mão de modo consciente e de que se espera um efeito na medida em que o leitor reconheça a apropriação.

Tendo em vista que na estrofe imediatamente anterior se fez referência à tabuinha de lápis-lazúli onde os trabalhos de Gilgámesh foram gravados, parece que se quer dar a entender que o conteúdo da dita inscrição é justamente a versão babilônica antiga. Trata-se, assim, de celebrar relações com a tradição letrada relativa a Gilgámesh, o que tem dois efeitos: o primeiro, garantir a fidelidade do que se narra, com o recurso à imagem do manuscrito encontrado (extensamente explorada em outras literaturas pelos séculos afora, com a condição de que se conte com a ideia de "literatura" enquanto inscrição); o segundo, ressaltar a própria criação de Sînlēqi-unninni como algo novo, na sequência da versão antiga.

Nesse sentido, GBGE, p. 446-447, observa como o tom da parte que se inicia é diverso do adotado na anterior, sendo constituído de três movimentos: a) três dísticos glorificando Gilgámesh por seu status e habilidade (v. 29-34); b) um dístico relativo a sua filiação (v. 35-36); c) finalmente, o terceiro movimento é dedicado a sua carreira (v. 37-44), num tom diferente, contudo, do proêmio, pois agora ressalta-se a grandeza das façanhas, não a dificuldade dos trabalhos. 
[33] Margem firme, abrigo da tropa,

Corrente furiosa que destroça baluartes de pedra. ${ }^{\star}$

[35] Amado touro de Lugalbanda, Gilgámesh perfeito em força,

Cria da sublime vaca, a vaca selvagem Nínsun.

[37] Alto é Gilgámesh, perfeito, terrível:

Abriu passagens nas montanhas,

[Verso 33-34] O termo kibru(m) designa a "margem" de um rio, de um córrego ou do mar, no sentido de um lugar firme, onde se pode estar a salvo. Cf. GBGE, p. 783, ainda que em textos literários não seja comum o uso da margem de um rio como imagem de proteção, percebe-se esse sentido na composição de nomes próprios como Ilī-kibrī (Meu deus é minha margem) e Kibrī-Dagān (Minha margem é Dagān). Considerando-se o imaginário mesopotâmico relativo a inundações, a figura ganha em significação. Note-se a antítese com a metáfora seguinte: Gilgámesh é, por um lado, a "margem firme" que fornece salvação contra a enchente, ao mesmo tempo que, por outro, é a própria "corrente furiosa que destroça os baluartes de pedra".

[Verso 35] Lugalbanda é considerado, na tradição dominante, o pai de Gilgámesh. Trata-se de um rei de Úruk divinizado, herói do poema sumério que leva seu nome. A expressão rīmu ša Lugalbanda dá margem, talvez intencionalmente, a vários entendimentos, tendo em vista a existência de termos homófonos ou quase: rìmu, "touro selvagem"; rīmu, "dom" dos deuses; rîmu, "amado" (cf. CDA, s. v.). Minha tradução ("amado touro") buscou preservar a mescla de sentidos possível.

[Verso 36] A mãe de Gilgámesh é Nínsun, deusa tutelar de Gudea e Lagash, filha dos deuses Ánu e Uras. Seu epíteto é "Vaca-Selvagem" (rìmat). Na tabuinha da Universidade da Pensilvânia que atesta a versão babilônica antiga do poema, em vez Rimat-Ninsun (a vaca selvagem Nínsun), lê-se rīmtum ša supūri(m) Ninsunna (touro selvagem do redil de Nínsun), cf. GBGE, p. 783.

[Versos 37-44] A sequência desses versos resume os feitos de Gilgámesh numa ordem crescente: a) ações civilizatórias (abriu passagens nas montanhas e cavou poços); b) ações relacionadas com sua busca pelo sentido da vida ou pela imortalidade (cruzou o mar até o sol nascente, palmilhou os quatro cantos da terra, visitou Uta-napíshti); c) ações visando à recuperação da memória destruída pelo dilúvio (reinstalou os templos e instituiu os ritos). Note-se como os três níveis se relacionam e, especialmente, como o coroamento de todos os trabalhos heroicos se encontra nessa reposição dos templos nos lugares de onde o dilúvio os varreu e, em consequência, na instituição (talvez recuperação) dos ritos também perdidos. 
[39] Cavou poços nas encostas do monte,

Cruzou o mar, o vasto oceano, até o sol nascente,

[41] Palmilhou os quatro cantos, em busca da vida,

Chegou, por sua força, ao remoto Uta-napíshti,

[43] Repôs os templos arrasados pelo dilúvio,

Instituiu ritos para toda a humanidade.

[45] Quem há que a ele se iguale em realeza

E como Gilgámesh diga: este sou eu, o rei?*

[47] A Gilgámesh, quando nasceu, renome lhe deram: ${ }^{\star}$

Dois terços ele é um deus, um terço é humano.

Assim, se a viagem até Uta-napíshti tinha como objetivo vencer a morte, inclusive de uma perspectiva marcadamente individual, já que não se tratava de conquistar a imortalidade para toda a humanidade, mas apenas para si, teve esta consequência um tanto inesperada: a aquisição de um saber que permite ao herói a reposição daquilo que, na esfera do serviço devido aos deuses, o dilúvio havia apagado ou, pelo menos, danificado.

Contra o que considera Silva Castillo, 2000, p. 14, parece que isso justifica plenamente a narrativa do dilúvio feita por Uta-napíshti, de que decorre o conhecimento referido já nos v. 7-8: ele viu o secreto, descobriu o coberto, trouxe e ensinou algo "que antes do dilúvio era”, o que não parece ser outra coisa que os templos e os ritos.

[Versos 45-46] Esses versos apresentam dificuldades de leitura, que GBGE, p. 785, resolve pelo acréscimo do pronome $\breve{s} a$ (que), com base em inscrição que constitui variante da fórmula do v. 45, lição e entendimento que sigo na tradução (com o que concorda também SEG, p. 92).

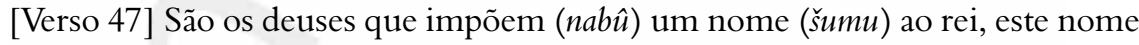
já definindo sua glória. SEG, p. 111, chama a atenção para a existência de outro verbo homófono em acádio (nabû ou neb̂u) com o significado de "brilhar", anotando que "provavelmente o texto joga com os dois significados: 'Gilgámesh' é o nome imposto e esse nome é, além do mais, brilhante, glorioso". Na tradução optei por "renome" para sugerir tanto a imposição do nome, quanto seu brilho.

[Verso 48] Essa é a expressão mais clara do caráter sobre-humano de Gilgámesh ("dois terços ele é deus, um terço é humano"). Esse dado é de enorme importância para a questão da imortalidade: ao fim e ao cabo, o que o herói aprenderá, depois de todos os trabalhos, é que ter dois terços de natureza divina não faz com que possa escapar da morte. 
[49] A forma de seu corpo, Bélet-1́li a desenhou, ${ }^{\star}$

Realizou sua forma física Nudímmud. *

[51] ---- majestoso ----

---- estatura ----

[53] ---- distância entre ----

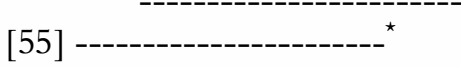
perna,

De três côvados é seu pé, metade de uma vara é sua

[Verso 49] Bēlet-ili significa "Senhora dos Deuses". Este é o nome sumério da grande Deusa-Mãe, correspondente a Arúru.

[Verso 50] Nudímmud é um dos nomes do deus Ea (ou ainda Enki), que reina no Apsû e tem como apanágio a sabedoria. No poema antropogônico Atra-hasīs, é ele que, como aliado da humanidade, ensina ao Supersábio (que aqui corresponde a Uta-napíshti) como fazer cessar os flagelos enviados pelos deuses com o fim de exterminar a raça humana, incluindo as instruções de como escapar do dilúvio. $\mathrm{O}$ dístico informa que a forma de Gilgámesh tendo sido configurada pela Senhora dos Deuses, é a Nudímmud que cabe fazer com que se realize no corpo do herói.

[Versos 51-55] Trecho bastante lacunar, embora GBGE, p. 540, creia que provavelmente nada se perdeu na passagem do v. 55 para o seguinte. Nas partes degradadas adoto as lições e o entendimento de GBGE (p. 540 e 785, 52), o que sugere que se trata aqui das proporções do corpo descomunal de Gilgámesh, descrição que tem continuidade a partir do v. 56.

[Verso 56] O texto afirma que o pé de Gilgámesh tinha a dimensão de 1 nikkassu, unidade de medida que, no antigo sistema babilônico, correspondia a 3 côvados, e, no recente, a 3,5 côvados. Considerando que o côvado (ammatu) equivale a por volta de 0,5 metro, conclui-se que o pé de Gilgámesh media em torno de $1,75 \mathrm{~m}$. A vara (nindanu) corresponde, no sistema antigo, a 12 côvados (por volta de $6 \mathrm{~m}$ ) e, no recente, a 14 (por volta de $7 \mathrm{~m}$ ), a perna do herói medindo, portanto, entre 3 e 3,5 m. GBGE, p. 785, chama a atenção para o fato de que a perna de Gilgámesh mediria "menos que o dobro de seu pé", concluindo que "evidentemente o texto está corrompido". 
[57] De seis côvados é o comprimento de seu passo,

---- côvados ---- de seu ----,

[59] Suas faces são barbudas como as de ----,

Os tufos do cabelo, exuberantes como Níssaba, ${ }^{\star}$

[61] Pelo talhe é perfeito em seu encanto,

Pelos padrões da terra, formoso é.

\section{Pastor de Úruk}

[63] Pelo redil de Úruk ele perambula,

Mandando como um touro selvagem altaneiro.

[Verso 57] Cf. GBGE, p. 785, a expressão birìt purīdi, que significa literalmente "espaço entre as pernas", pode também designar a parte alta da coxa ou a virilha. Considerando que a medida, neste caso, seria de 6 côvados ou cerca de 3 metros, o que equivale ao comprimento das pernas de Gilgámesh, a proporção aplicada a seu passo parece correta. Isso corresponde ao dobro da medida convencional do "passo" (purīdu) na metrologia babilônica, ou seja, 3 côvados (mais ou menos 1,5 m).

[Verso 58] Neste verso lê-se ammat ašaritti šs $[a . .$.$] tešu, o primeiro termo significando$ "côvados", o segundo tendo um sentido desconhecido, devendo designar alguma parte do corpo (tantos côvados mede tal parte do corpo) e o terceiro estando bastante corrompido. Cf. GBGE, p. 785, Tournay e Shaffer sugerem que se trate do polegar, restaurando ša [ubāna]tě̌u, o termo ubānu tendo o significado de "dedo" (ašaritti ša ubāna devendo significar, portanto, "dedo polegar").

[Verso 60] Este verso é restaurado a partir do v. 107 ("os tufos de seu cabelo exuberantes como Níssaba”), em que está em causa Enkídu. A imagem alude ao grão "cabeludo" da cevada madura, a deusa Níssaba (Nísaba ou Nídaba) tendo o "cabelo de cevada amarrado em grossos feixes" (cf. GBGE, p. 785-786, em que se apresentam exemplos relativos à deusa). Níssaba estava tradicionalmente relacionada com esse cereal e, posteriormente, também com a contabilidade e a escrita. O pictograma que a representava desde a época suméria era uma espiga de cevada, sendo cultuada desde a época dinástica antiga e considerada irmã de An e Úrash. Fazia parte do panteão de Lagash, onde era tida por irmã de Énlil. Em época posterior, por sua relação com a escrita, foi considerada esposa do deusescriba Nabû. Como termo comum, nissabu/nissaba significa "cevada" (CDA, s.v.).

[Verso 63] Neste ponto tem início a narrativa propriamente dita, com a exposição dos atos de Gilgámesh em Úruk, marcados pelo excesso, em consonância, aliás, com sua natureza fora do comum, tal qual acabou de ser apresentada. 
[65] Não tem rival se levanta seu taco,

Pela bola os companheiros levantam. ${ }^{\star}$

[67] Assedia os jovens de Úruk sem razão,

Não deixa Gilgámesh filho livre a seu pai.

[69] Dia e noite age com arrogância

Gilgámesh rei ---- uma multidão guia.

[71] Ele, o pastor de Úruk, o redil,

Não deixa Gilgámesh filha livre a sua mãe.

[73] ---- logo ----

Suas queixas ---- diante dele:

[75] Poderoso, magnífico, sapiente,

Não deixa Gilgámesh moça livre a seu noivo.

[77] À filha do guerreiro, à esposa do jovem,

Ouviram-lhes as queixas as deusas.

[79] Os deuses dos céus, senhores do comando,

[Versos 65-66] Trata-se de trecho de leitura duvidosa (cf. GBGE, p. 786-786). A referência parece ser ao jogo com pukku (bola) e mukkû (taco), em que Gilgámesh se destaca (cf. o que se afirma em 12, 4-5). Observe-se a estratégica repetição do verbo "levantar" (teb̂), aplicado tanto ao taco de Gilgámesh quanto aos próprios companheiros nos esportes.

[Verso 67] "Sem razão", conforme a sugestão de SEG, p. 111, traduz ina ku-k [itti], ou seja, "com algo que está fora de lugar" (GBGE traduz a expressão como wrongfully, "injustamente").

[Versos 73-74] Este dístico encontra-se muito pouco preservado (cf. GBGE, p. 786), parecendo que narra como as mulheres começaram a lamentar-se diante dos deuses. O conteúdo de sua súplica encontra-se em 75-76, remetendo ao narrado nos v. 67-72.

[Verso 76] Não é fácil saber a que se referem o v. 68 (Gilgámesh "não deixa filho livre a seu pai") e o v. 72 ("não deixa filha livre a sua mãe"), mas parece que o v. 76, que repete a mesma fórmula com variações ("não deixa Gilgámesh moça livre a seu noivo"), remete ao direito de o rei desfrutar da primeira noite com a noiva. Isso fica mais claro tendo em vista a referência (que imediatamente segue) à súplica da "filha do guerreiro" e da "esposa do jovem" às deusas, a qual, no v. 91, termina com repetição do v. 76 ("não deixa Gilgámesh moça livre a seu noivo").

[Verso 78] Não fica claro a que "deusas" o texto se refere. Como anota GBGE, p. 787-788, o verbo exige um sujeito no plural, embora o termo que se lê seja ištaru, "deusa". Parece que se trata, neste caso, de um uso como coletivo. 
---- [disseram a Ánu] ----:

[81] Criaste agressivo touro selvagem em Úruk, o redil:

Não tem rival se levanta seu taco,

[83] Pela bola os companheiros levantam,

Assedia os jovens de Úruk sem razão,

[85] Não deixa Gilgámesh um filho livre a seu pai,

Dia e noite age com arrogância.

[87] Pastor de Úruk, o redil,

Gilgámesh rei --- uma multidão guia.

[89] Ele é o seu pastor e ----

Poderoso, magnífico, sapiente,

Não deixa Gilgámesh filha livre a sua mãe.

\section{A criação de Enkídu}

[92] À filha do guerreiro, à esposa do jovem,

Ouviu-lhes as queixas Ánu.

[94] A Arúru, grande rainha:

[Verso 79] A expressão bēl zikri (que traduzi como "senhores do comando") oferece alguma dificuldade de interpretação. Esclarece GBGE, p. 788, que zikru significa "uma ideia ou iniciativa", acrescentando: "O epíteto bēl zikri deve provavelmente ser entendido como uma referência ao fato de que os deuses do céu, nesse período os Igígu, eram os que podiam tomar iniciativas na assembleia divina, ao contrário das divindades confinadas no mundo subterrâneo. Nessa condição, eles tinham talvez a obrigação, uma vez que as queixas do povo de Úruk chegaram até eles, de fazer algo para resolver o problema. Assim, eles chamam a atenção dos poderes mais altos para essas queixas".

[Verso 80] Verso muito danificado, que, todavia, considerando-se a sequência da ação, deve servir para introduzir o discurso direto que segue, dirigido provavelmente a Ánu (cf. GBGE, p. 788), o deus principal do panteão babilônico e o patrono de Úruk.

[Verso 88] Verso muito danificado, reconstituído com base no v. 70.

[Verso 93] Em seguida a este verso, uma tabuinha babilônica média contendo um exercício escolar, procedente de Nippur (MB Nippur1), descreve a reação dos deuses: um dos deuses (cf. SEG, p. 95, seria Ea/Nudímmud) ordena que seja chamada Arúru (a Senhora dos Deuses, Bèlet-ili), pois foi ela quem criou a numerosa humanidade; ordena ele que agora crie um rival para Gilgámesh, a fim de que se enfrentem um ao outro e deixem Úruk em paz; Arúru é então chamada e se lhe repete a ordem. 
Tu, Arúru, fizeste a raça humana!

[96] Agora faze o que se disse:

Que um coração tempestuoso se lhe oponha,

[98] Rivalizem entre si e Úruk fique em paz!

Arúru, isso quando ouviu,

[100] O dito de Ánu concebeu no coração.

Arúru lavou as mãos,

[102] Pegou de argila e jogou na estepe: ${ }^{\star}$

$\mathrm{Na}$ estepe a Enkídu ela criou, o guerreiro,

[104] Filho do silêncio, rocha de Ninurta,

[Verso 94] Arúru é um dos nomes da grande deusa-mãe, já referida no v. 49 como Bèlet-ili, Senhora dos Deuses. No texto lê-se apenas dAruru issû rabìtu (Arúru grande rainha), o que GBGE, p. 543, traduz como "They summoned Aruru, the great one", e SEG, p. 96, "Citaron a Aruru, la gran señora". Apenas acrescentei ao verso a preposição "a”, para dar a entender que o que se segue constitui o que disseram os deuses a Arúru.

[Verso 100] Os manuscritos registram a variante Énlil (em vez de Ánu, cf. GBGE, p. 545).

[Verso 102] Cf. GBGE, p. 789, este verso e o seguinte constituem a única citação que se conhece de Ele o abismo viu, a qual se encontra num comentário sobre um texto de prognósticos e diagnósticos (Sakikku I), para comprovar que a humanidade foi feita de argila.

[Verso 103] Enkídu é um nome sumério cuja forma mais antiga é en.ki.dùg; aparece em geral na documentação acádia como en-ki-du e raramente como en-kitu (supondo-se que a penúltima sílaba fosse longa na poesia babilônica: Enkìdu); na tradução do poema para o hitita, o nome apresenta ainda a forma en.gi.du ou en.ki.ta mais terminação de caso. O sentido do termo em sumério é "senhor do lugar agradável", a proposta de que pudesse significar "Enki o criou" (equivalente ao acádio Eabāni, "Ea o criou") mostrando-se inconsistente, ainda que se admita que, no final do segundo milênio, o nome possa ter sido interpretado dessa forma, de acordo com o gosto por etimologias então em curso (cf. Worthington, 2011, p. 409-414, teria sido Shámhat, a prostituta, que teria, no verso 174 abaixo, nomeado Enkídu, seu nome sendo de início uma exclamação com o significado de "feito por Enki!" ou algo semelhante). 
Pelos sem corte por todo o corpo,

[106] Cabelos arrumados como de mulher:

Os tufos do cabelo, exuberantes como Níssaba,

[108] Não conhece ele gente nem pátria,

Enkídu aparece como companheiro de Gilgámesh desde os textos em sumério, em que se registram duas tradições divergentes: numa ele é chamado de "servo" de Gilgámesh (este sendo considerado o lugal, isto é, o rei de Enkídu); noutra, especialmente concernente à morte de Gilgámesh, ele é referido como um amigo precioso. Enkídu não aparece fora do ciclo de Gilgámesh, a não ser num encantamento babilônico antigo (cf. GBGE, p. 138-144). Reconhece-se que um traço distintivo do poema de Sîn-lēqi-unninni (tão importante quanto a exploração da temática da mortalidade) é o papel nele atribuído a Enkídu como efetivo companheiro e igual de Gilgámesh (cf. Sasson, 1972, p. 265-266).

O termo qurādu $(m)$, "guerreiro", "herói" (derivado de qarādu, "ser belicoso"), com que se qualifica Enkídu neste verso, é o mesmo que aparece nos v. 77 e 92 acima. Este é o traço por excelência de Enkídu, aquele que torna possível que ele cumpra a função que preside a sua criação, expressa nos v. 97-98: "Que um coração tempestuoso se lhe oponha [a Gilgámesh],/ Rivalizem entre si e Úruk fique em paz".

[Verso 104] A expressão ilitti qulti, que traduzi como "filho do silêncio", tem provocado dúvidas entre os intérpretes no que concerne a seu significado. Pareceme que a opinião de George é a mais adequada: o modo como nasceu Enkídu torna-o ímpar, pois, enquanto os demais homens foram dados à luz no meio dos gritos e gemidos da mãe, sua entrada no mundo foi cercada de silêncio (GBGE, p. 789). Registre-se que há uma variante deste hemistíquio assim restaurada: i-lit!-tu4 $m u-t[u m ?$ ? o termo $m \bar{u} t u(m)$ significando "morte" (filho da morte).

No segundo hemistíquio lê-se kişir dninurta (força de Ninurta). Kișrum significa "nó", "amarração" com junco, com corda; "concentração", "grupo", "aglomeração", "aglomerado"; aplicado a montanhas (kişrăt ša de "rocha", "pedra"; determinado por um nome divino, kişir significa "fortalecido", "sustentado" por um deus (cf. kașāru(m), "amarrar", "dar um nó”, "juntar", "reunir"). Como está em causa o deus Ninurta, a expressão indica que é ele quem dá consistência e sustentação a Enkídu. Ninurta era associado a grandes feitos guerreiros, especialmente em combates singulares contra um rival valoroso, como caberá também a Enkídu enfrentar Gilgámesh. Minha tradução por "rocha de Ninurta" leva em conta a nova ocorrência de kişrum, aplicado pelo caçador a Enkídu, no v. 125.

[Verso 107] Recorde-se que a mesma expressão descreve Gilgámesh no v. 60 supra. 
Pelado em pelo como Shákkan,

[110] Com as gazelas ele come grama.

Com o rebanho na cacimba se aperta,

Com os animais a água lhe alegra o coração.

\section{Enkídu e o caçador}

[113] Um caçador, homem de armadilhas,

No açude com ele deu de cara.

[115] Um dia, um segundo, um terceiro, no açude deu com ele,

[Verso 108] Em vez de "gente" (niš̄i) registra-se também a variante "deus" (dingir). O termo nišs $(m)$ significa "povo", "humanidade", "população" e também "parentes", "família". Uma leitura possível poderia ser, portanto, "não conhece ele família nem pátria". Caso se opte pela variante "não conhece ele deuses nem pátria”, a questão estará em saber se esses "deuses" poderiam ser tidos como os tutelares (os $\check{s} \bar{e} d u$ ) ou como os ancestrais mortos (cf. GBGE, p. 789-790).

[Verso 109] Shákkan é o senhor dos animais, deus do gado, que se representava nu em pelo. A expressão lubuti labiš kima Šakkan (vestindo veste como a de Shákkan) indica que Enkídu se cobre não mais que com os pelos do próprio corpo, como não poderia deixar de acontecer no período em que vive na companhia dos animais, sem conhecer gente nem cidade. Ao traduzir a expressão por "pelado em pelo", pretendo também manter algo da aliteração a que a ocorrência de objeto direto interno dá margem em lubuti labiš (cf. labāsu labiš, "vestir uma veste").

[Verso 110] As gazelas são animais especialmente relacionados com Shákkan, chamado de "senhor das gazelas" (cf. GBGE, p. 790).

[Verso 111] Como acontece em regiões desérticas, essas “cacimbas" (masqu) são construídas em depressões do terreno, podendo contar com muros (em geral de barro) para conter a água. Por isso se fala que Enkídu e os animais se apertam no local.

[Verso 114] Começa novo episódio da trama em que se destacam dois aspectos: a insistência no caráter extraordinário da figura de Enkídu, em descrição feita agora pelas personagens; e os percursos dessa informação até chegar ao conhecimento de Gilgámesh (o que diz o caçador a seu pai; o que diz o pai ao caçador; o que diz o caçador a Gilgámesh). 
Viu-o o caçador, enregelou-lhe a face.

[117] Ele e seus bichos a casa voltaram:

Aterrorizado, em silêncio, atento,

[119] ---- seu coração, sua face como um dia sombrio,

Havia tristeza em suas entranhas,

À de quem chega de longe sua face se iguala. ${ }^{\star}$

[122] O caçador a boca abriu para falar e disse ao pai:

Pai, há um homem que vai ao açude,

[124] No país é ele que mais força tem,

Como uma rocha de Ánu é sua poderosa força.

[126] Vagueia sobre os montes todo o dia,

[Verso 117] Não fica claro a quem este verso se refere, se a Enkídu ou ao caçador. George argumenta que a presença do pronome šù indica uma mudança do sujeito, logo, trata-se de Enkídu (GBGE, p. 791).

[Versos 118-121] Fica também ambíguo a quem se atribuem essas reações, se a Enkídu ou ao caçador. Caso se opte pelo segundo, trata-se de uma simples introdução ao que ele dirá ao pai; caso a referência seja a Enkídu, essas reações funcionam como uma espécie de pano de fundo, deixado em suspense enquanto a ação se desenrola no outro plano, até que tudo desemboque no impactante encontro com a prostituta.

[Versos 120-121] Este dístico repete-se mais de uma vez na tabuinha 10, sempre aplicado a Gilgámesh, seja pelo narrador (v. 9-10), seja pelas personagens, a saber, a taberneira Shidúri (42-43), o barqueiro Ur-shánabi (115-116) e Uta-napíshti (215-216); em suas respostas às falas das três personagens, é o próprio Gilgámesh que também aplica os mesmos termos a si ([49-50], 122-123 e 222-223).

[Verso 122] Trata-se de uma fórmula para a introdução de discursos diretos, aqui na sua versão mais longa.

[Versos 123-132] O conteúdo do que diz o caçador a seu pai implica uma mudança de foco relativa à descrição de Enkídu. Até então tudo o que se sabia dele era devido ao narrador, que goza do predicado da onisciência: sua origem, sua figura, sua vida entre os animais. Agora, o leitor é conduzido pelo olho do caçador, que realça o quanto Enkídu se contrapõe ao mundo civilizado (ver Dickson, 2007, p. 171-174). 
Não para de com o gado comer grama,

[128] Não para de deixar a pegada no açude,

Estou com medo e não chego junto dele.

[130] Encheu os buracos que cavei eu mesmo,

Desatou as redes que estendi.

[132] Tirou-me das mãos os bichos, os animais da estepe,

Não me deixa já o trabalho na estepe.

[134] O pai abriu a boca para falar e ao caçador disse:

Meu filho, ---- Úruk, Gilgámesh, ${ }^{\star}$

[136] ---- com ele,

[Verso 125] É por conjetura que se reconstitui [kima kişri] ša danim, "[como uma rocha] de Ánu", as palavras entre colchetes não se podendo ler no original. $\mathrm{O}$ termo kişrum é aplicado a Enkídu no v. 104, determinado pelo nome de outro deus, Ninurta (traduzi a expressão por "rocha de Ninurta"). Aqui, considerando que Ánu é o deus celeste, seria possível entender a expressão simplesmente como "rocha do céu" ou "pedaço de rocha do céu", como faz GBGE, p. 545. Sanmartín observa que o que está em questão é "a força atribuída a um meteorito, mais exatamente, ao ferro de origem sideral”, considerando-se inclusive a repetição de kima kişru ša danim no v. 248 abaixo, em que está em causa uma chuva de meteoritos (SEG, p. 112).

[verso 129] O segundo hemistíquio deste verso (repetido no v. 156), ul ațehha ana šâšu ("não chego junto dele"), ecoa no dos v. 144 e 165, ițehha ana šâši ("chegará junto dela", em que, primeiramente, o pai do caçador e, depois, Gilgámesh afirmam que Enkídu se aproximará da prostituta Shámhat, que deve ser levada até ele), bem como volta a ecoar no v. 183, ițehha ana kâši ("chegará junto de ti", dito pelo caçador à prostituta), o verbo țeh $\hat{u}(m)$ tendo o significado de "estar perto", "chegar perto", "aproximar-se", inclusive, quando aplicado a pessoas e animais, para relação sexual. Worthington, 2011, p. 416-417, chama a atenção para nova ocorrência do mesmo termo na tabuinha 7, 105, quando Enkídu, à beira da morte, lança uma maldição contra Shámhat, izrūya liţhûki kâši ("minha maldição chegue junto de ti", isto é, "minha maldição te aflija").

[verso 131] O termo que traduzi por "rede" (nuballu) designa propriamente "asa", em especial a da águia. Cf. GBGE, p. 794, deve tratar-se aqui de "uma rede em forma de asa".

[Versos 135-136] Apesar de mal conservados, não há dúvida de que nestes versos o pai envia o caçador a Gilgámesh. 


\section{Como uma rocha de Ánu é sua poderosa força.}

[138] Pega o caminho, para o coração de Úruk volta a face, ---- homem forte,

[140] Vai, filho, contigo leva a meretriz Shámhat, ---- como um forte.

[142] Quando os bichos se aproximem do açude,

[Verso 137] Verso idêntico ao 121, que se referia a Enkídu. Neste caso, o que dele se lê é somente a última parte: $d u-n] u-n a$ e-mu-qa-a-šu , isto é, "sua poderosa força”. Que a mesma expressão seja aplicada tanto a Enkídu quanto a Gilgámesh reforça a paridade entre os dois.

[Verso 138] Este verso é reconstituído com base no v. 148 abaixo, em que o narrador conta como se realizou o nele ordenado. A expressão ina libbi urukk tem o sentido comum de "a Úruk" ou "ao interior de Úruk". Optei, todavia, por uma tradução literal ("para o coração de Úruk"), a fim de não perder o belo uso de libbu (m), isto é, "coração", num torneio bastante típico das línguas semíticas.

[Verso 139] Só se lê ša emuq LÚ, literalmente "força de homem"; George, 2003, p. 6, reconstitui assim: "não confies na força de um homem".

[Versos 140-145] Estes versos são reconstituídos a partir dos v. 162-166 (em que não se repete o v. 141, apenas fragmentariamente conservado).

[Verso 140] Shámhat é uma personagem-chave no relato, como se verá a seguir, pois a ela compete humanizar Enkídu, tanto por meio do contato sexual, quanto pelos ensinamentos relativos à vida civilizada. Não tem razão Bailey, 1970, p. 140, quando afirma que se trata de personagem anônima e, portanto, mal delineada, tendo em vista que šamhatum significa "prostituta" (trata-se de adjetivo com o sentido de "voluptuoso", termo derivado de šamhu(m), "luxuriante", "viçoso", quando aplicado a vegetação e pessoas, do verbo šamāhu $(m)$, "crescer", "florescer", "atingir uma extraordinária beleza e estatura”). Que Shámhat não seja um nome próprio constitui um entendimento outrora comum: assim SGG, p. 36-38, o traduz como "moça”. Ora, nos versos 162 e 167, a partir dos quais este é reconstituído, lê-se harimtu fšamhat, o primeiro termo tendo já o significado de "prostituta do templo" (derivado de harāmu, "separar", no sentido de que se trata de mulheres que viviam isoladas num recinto determinado do templo), não sendo razoável supor que o segundo signifique a mesma coisa, em vez de tratar-se de um nome próprio que evidentemente joga com os sentidos derivados de šamāhu $(m)$, apontando para o viço e a voluptuosidade da mulher, considerada, conforme George, como "a 
Tire ela a roupa e abra seu sexo. ${ }^{\star}$

[144] Ele a verá e chegará junto dela,

Estranhá-lo-á seu rebanho, ao que cresceu com ele. [146] Ao conselho do pai ----

conforme George, como "a prostituta por excelência". Saliente-se que esse nome aparece como próprio em outros documentos (cf. GBGE, p. 148). A propósito da nomeação de Shámhat por Enkídu como um importante recurso narratológico, ver Worthington, 2011, p. 406-409.

Desde a descrição feita por Heródoto da prostituição nos templos da Babilônia (cf. Histórias 1, 199), muito se tem especulado sobre o estatuto dessas hierodulas. Pelo que hoje se sabe, parece que as harimtu constituíam uma das classes de mulheres ligadas aos templos (cf. Lerner, 1985, p. 244, provavelmente a mais baixa dentre todas, constituída por "filhas de escravas" que ficavam "sob a supervisão de um funcionário de nível inferior"). O texto não diz nada sobre a condição de Shámhat, mas George anota que, "enquanto um centro do culto a Ishtar, deusa do amor sexual, Úruk era uma cidade bem conhecida pelo número e beleza de suas prostitutas", muitas delas empregadas no templo de Nínsun e da própria Ishtar; uma vez que ela conduz Enkídu ao templo de Ánu e desta última deusa, é de supor-se que estivesse ligada justamente a ele (GBGE, p. 148).

Escolhi um termo menos usual e já um tanto arcaico para traduzir harimtu, ou seja, "meretriz", a fim de sugerir de algum modo que não se trata de uma prostituta no sentido comum (eu quis evitar, igualmente, a palavra grega "hierodula").

[Verso 143] Cf. SEG, p. 113, "na iconografia mesopotâmica são muito frequentes as representações de uma figura feminina que abre seu manto e deixa descoberto seu sexo; trata-se do ato de provocação típico de uma prostituta”.

[Verso 144] Como já observei, o verbo țeĥ̂ (chegar, aproximar-se) é usado frequentemente no sentido da obtenção de contato sexual.

[Verso 145] Segundo alguns comentadores, o fato de Enkídu, por ter tido relações sexuais com Shámhat, passar a ser estranhado pelos animais com os quais vivia até então sugere algum tipo de zoofilia (assim interpreta SEG, p. 113: "a atração sexual por Shámhat destruirá as relações zoofílicas de Enkídu"). Nada no texto explicita isso, mas não se trata de algo absurdo a ser simplesmente descartado. 


\section{O caçador partiu ---- \\ O caçador e Gilgámesh}

[148] Pegou o caminho, para o coração de Úruk voltou a face,

Ao rei Gilgámesh ----:

[150] Há um homem que vai ao açude,

No país é ele que mais força tem:

[152] Como uma rocha de Ánu é sua poderosa força,

Vagueia sobre os montes todo o dia,

[154] Não para de com o gado comer grama,

Não para de deixar a pegada no açude.

[156] Estou com medo e não me aproximo dele,

Encheu os buracos que cavei eu mesmo,

[158] Desatou os laços que estendi,

Tirou-me das mãos os bichos, os animais da estepe,

Não me deixa já o trabalho na estepe.

[161] Gilgámesh a ele diz, ao caçador: ${ }^{\star}$

Vai, caçador, contigo leva a meretriz Shámhat.

[163] Quando os bichos se aproximem do açude,

Tire ela a roupa e abra seu sexo.

[165] Ele a verá e chegará junto dela,

Estranhá-lo-á seu rebanho, ao que cresceu com ele.

\section{Shámhat e Enkídu}

[167] Partiu o caçador, consigo levou a meretriz Shámhat,

Pegaram o caminho, empreenderam a jornada, [169] No terceiro dia, ao lugar aprazado chegaram.

Observe-se como os v. 142-145 se estruturam para ressaltar justamente a incompatibilidade entre a convivência de Enkídu com os animais e com a mulher: os v. 142 e 145, referindo-se ao rebanho, envolvem os dois versos que relatam o encontro com Shámhat (v. 143 e 144). Não há dúvida, portanto, que é pela relação sexual com a mulher que se procede à mudança no estatuto de Enkídu, o que representa de modo igual uma inflexão na narrativa.

[Verso 161] Trata-se de uma outra fórmula, menos frequente, de introdução de discurso direto, que aqui aparece pela primeira vez. 
O caçador e a meretriz de tocaia sentaram-se.

[171] Um dia, um segundo dia no açude sentados ficaram;

Chegou o rebanho, bebeu no açude,

[173] Chegam os animais, a água lhes alegra o coração,

E também ele: Enkídu! Seu berço são os montes!

[175] Com as gazelas ele come grama,

[Verso 169] No texto se lê ina eqela ša adanni, que traduzi por ("no lugar aprazado"). O sentido primeiro do termo adannu é temporal: "data", "prazo", podendo ser também usado em acepção espacial (a expressão eqel adanni significa "objetivo"). Com "lugar aprazado" busco preservar o jogo entre tempo e espaço.

[Verso 170] O termo que traduzi como "tocaia", ušbu, é um hápax legómenon cujo sentido dá margem a dúvida (cf. GBGE, p. 795). Admite-se em geral que signifique "esconderijo", "covil".

[Verso 174] Este verso, $u$ šu enkidu ilittašu šadumma, oferece alguma dificuldade de leitura, que leva George e Sanmartín a articularem o primeiro e o segundo hemistíquio através de um pronome relativo: "and also Enkidu himself, whose birthplace was the hills" (GBGE, p. 548); "y el mismísimo Enkidu, que tuvo a las colinas por cuna" (SEG, p. 100). O mesmo George (The Epic of Gilgamesh, p. 7) dispensa o relativo: "and Enkidu also, born in the uplands". Minha tradução vai nesta última direção, procurando valorizar a organização paratática dos dois hemistíquios.

Deve-se levar em conta a sugestão de Worthington, 2011, p. 401-414, que propõe entender o verso desta maneira, "and... that one! Enkidu (lit. 'one made by Enki' or sim.). He is born of the mountains", com base em dupla justificativa: a primeira, respeitar a sintaxe do original; a segunda, considerando as teorias narratológicas concernentes às técnicas de focalização, que essa espantada percepção de Enkídu deve ser atribuída a Shámhat, a qual o vê pela primeira vez. De modo mais ousado, defende ele que é a própria Shámhat quem nomeia Enkídu, o qual, vivendo na estepe, longe do convívio humano, careceria até então de nome próprio; de fato, a única ocorrência de seu nome até este ponto se encontrava no verso 103, devido ao narrador: "Na estepe a Enkídu ela criou, o guerreiro", estando em causa a criação do herói por Arúru. É dessa perspectiva que o mesmo comentador recupera a suposta etimologia "feito por Enki" ou algo semelhante, justificando que, na verdade, se trata do grito de espanto de Shámhat. Esse mesmo espanto justificaria a forma um tanto assintática do verso. 
Com o rebanho aperta-se na cacimba,

[177] Com os animais a água lhe alegra o coração.

E viu-o Shámhat, ao homem primevo,

mancebo feroz do meio da estepe.

[180] Este é ele, Shámhat! Oferece os seios!

Abre teu púbis e que ele toque teu sexo!

[182] Não tenhas medo, toma seu alento! ${ }^{\star}$

É ainda com base na focalização em Shámhat que sugere Worthington se deva resolver a aparente inconsistência contida no segundo hemistíquio, em que se afirma que o berço (ilittu) de Enkídu são os montes (šadu), quando se disse antes que ele foi criado na estepe (șêru, v. 102). Não se trata de uma informação (que Shámhat, aliás, não poderia ter), mas da verbalização da impressão que Enkídu lhe causa à primeira vista: um ser assim tão fora do comum e apenas meio humano só poderia ser filho das montanhas. Observe-se que a mesma expressão ilittašu šadumma volta a ocorrer em 2, 42, como parte do discurso direto dos pastores que contemplam, também pela primeira vez, Enkídu (ou seja, trata-se de uma nova focalização e da expressão do espanto da parte das personagens cujo foco então se adota).

[Verso 178] Com "homem primevo" traduzo lullâ amèla. O termo amēlu é sinônimo de awìlu e significa "homem"; lullû designa em geral o primeiro protótipo de homem criado pelos deuses (Bottéro traduz como "ébauche d'homme", isto é, "rascunho de homem"). Como resume SEG, p. 113, nesta passagem lullu "parece corresponder a uma visão quase evolucionista da origem do homem; é um estado pré-humano, caracterizado pela selvageria e o zoomorfismo. Nos mitos de criação babilônicos, o lullû é o primeiro momento do ser pré-humano: um projeto que necessita de outros complementos para converter-se em 'homem'". A palavra é usada por Uta-napíshti em 10,318, quando ele afirma a inelutabilidade da morte para o ser humano.

[Verso 179] O que traduzi por "mancebo feroz" é etla šaggāša, em que etlu(m) nomeia o "homem" por oposição a "mulher", no sentido de "viril", "homem jovem", e $\check{s} a g g \bar{a} \breve{s} u(m)$ significa "assassino", aplicado a pessoas, demônios etc. (cf. šagăšu $(m)$, "matar", "chacina", e também "maltratar"). Ainda que se pudesse optar por traduzir a expressão literalmente ("mancebo assassino", como faz GBGE, p. 549: "a murderous fellow"), trata-se naturalmente de imagem que visa a ressaltar a ferocidade de Enkídu, pois ele não é apresentado em nenhum momento matando pessoa ou animal (como um animal carnívoro), mas, pelo contrário, apenas alimentando-se de ervas, com as gazelas.

[Verso 180] A expressão que traduzi como “oferece os seios" é rumi kirimiki, o último termo, kirimmu, designando a dobra que se faz com os braços, especialmente 
Ele te verá e chegará junto de ti:

[184] A roupa estende, deixa-o deitar-se sobre ti,

E faz com esse primitivo o que faz uma mulher:

[186] Seu desejo se excitará por ti,

Estranhá-lo-á seu rebanho, ao que cresceu com ele.

[188] Abandonou Shámhat os vestidos,

Abriu seu púbis e ele tocou seu sexo,

[190] Não teve ela medo, tomou seu alento,

A roupa estendeu, deixou-o deitar-se sobre si,

[192] Fez com esse primitivo o que faz uma mulher

para sustentar uma criança. Ao desdobrar os braços (provavelmente preparandose para abraçar o parceiro), a prostituta ao mesmo tempo expõe os seios.

[Verso 182] São várias as propostas de interpretação do sentido do segundo hemistíquio (napissu lequ, "toma seu alento"): a) aproximar-se a ponto de sentir a respiração do outro; b) abraçar; c) respirar o cheiro de Enkídu (seu mau cheiro); d) tratar-se-ia de uma expressão eufemística, napǐš fazendo referência aos órgãos sexuais excitados ou ao ardor de Enkídu; d) trata-se de uma "linguagem de caçador": Shámhat deve mover-se suficientemente perto de sua presa, de modo a capturá-la (cf. GBGE, p. 796; SEG, p. 102; SGG, p. 37).

[Verso 186] Este verso impõe bastante dificuldade de entendimento, por dois motivos: em primeiro lugar, conforme o CAD, o verbo habübu apresenta dois sentidos: referido a animais, "gorjear", "zumbir", "silvar"; referido a humanos, "murmurar" e, especialmente em contexto erótico, "sussurrar"; por outro lado, esta é a única passagem em que ele aparece tendo como sujeito dādu, "amor", "amado", "fazer amor", podendo também ser usado como eufemismo para a região genital tanto do homem quanto da mulher (cf. GBGE, p. 796-797). Uma tradução literal seria "seu amor sussurrará por ti". Concorda-se, todavia, que o verbo, em contexto erótico, faça referência tanto ao contato físico (carícias) como aos ruídos (sussurros, gemidos) da relação sexual (cf. traduzem GBGE, p. 549, "his 'love' will caress and embrace you"; SEG, p. 102, "su sexo te acariciará"; George, The Epic of Gilgamesh, p. 6, "Let his passion caress and embrace him"). Minha opção ("seu desejo se excitará por ti”) teve como objetivo manter a dupla conotação envolvendo contato e ruídos, levando em conta também a possibilidade de manter a mesma tradução para habūbu no v. 256 abaixo.

Este verso apresenta uma variante: "teu desejo se excitará por ele". 
E o desejo dele se excitou por ela.

[194] Seis dias e sete noites Enkídu esteve ereto e copulou com Shámhat.

Depois de farto de seus encantos,

[196] Sua face voltou para seu rebanho.

Viram-no, a Enkídu, e se puseram a correr,

[198] Os bichos da estepe fugiram de sua figura:

Contaminara Enkídu a pureza de seu corpo,

[200] Inertes tinha os joelhos, enquanto os bichos avançavam,

Diminuído estava Enkídu, não como antes corria.

[202] Mas agora tinha ele entendimento, amplidão de saber.

Voltou a sentar-se aos pés da meretriz.

[Verso 194] Este período de tempo ("seis dias e sete noites") volta a aparecer em outros pontos importantes do poema: a duração dos funerais de Enkídu (10, 58 etc.); a duração do dilúvio $(11,128)$; o período sem sono que Uta-napíshti prescreve para Gilgámesh $(11,209)$.

O manuscrito de Pensilvânia oferece, para esta passagem, a variante "sete dias e sete noites”, que é comum também para as outras ocorrências (cf. GBGE, p. 797).

[Versos 199-202] Note-se como se apresenta como complexa a iniciação de Enkídu no mundo humano e civilizado, o que, conforme Bailey (1970, p. 142), é "uma medida da grandeza deste épico" que pinta tal entrecho como algo que implica, ao mesmo tempo, "ganhos e perdas". Com efeito, ele ganha em inteligência ao preço da perda de parte de sua capacidade física, não tendo mais a velocidade das gazelas.

[Verso 202] Observa SEG, p. 114: "Enkídu já não é um lullû, 'quase-homem, semi-homem', projeto inacabado de humanidade, mas um homem feito e acabado, tanto física quanto mentalmente".

A expressão que traduzi por "amplidão de saber" é rapaš hasīsa, em que o último termo (hasīsum) tem como primeiro sentido "orelha", "ouvido", "audição" e, a partir daí, "compreensão", "sabedoria", como no nome próprio Atra(m)-hasīs, "muito sábio". Essa relação do conhecimento com a audição parece própria das culturas semíticas, em que o ouvido tem a função que, entre os gregos, se atribui preferentemente ao olho enquanto fonte de conhecimento. Nos versos seguintes, especialmente no 205, fica claro como se dá essa aquisição de sabedoria pelo ouvido. 
A sabedoria de Shámhat

[204] A meretriz olhou ele seu rosto,

E o que a meretriz fala escutam seus ouvidos, [206] A meretriz a ele diz, a Enkídu:

És bom, Enkídu, como um deus és tu! ${ }^{\star}$

[208] Por que vagas com os animais pela estepe?

Vem! Levar-te-ei ao coração de Úruk, o redil, [210] À casa dos deuses, morada de Ánu e Ishtar,

Onde também está Gilgámesh, perfeito em força,

[212] E como touro selvagem tem ele poder sobre os homens.

Ela falava e ele assentia com suas palavras,

[214] Seu coração sagaz buscava um amigo. ${ }^{\star}$

Enkídu a ela diz, à meretriz:

[216] Vem, Shámhat, convida-me

À casa dos deuses, morada pura de Ánu e Ishtar,

[218] Onde também está Gilgámesh, perfeito em força,

E como touro selvagem tem ele poder sobre os homens.

[Versos 203-206] Note-se a enfática repetição de meretriz, harimti/harimtu(m), nesses versos, em posições variadas nos sintagmas (o que mantive na tradução), reforçando o papel de Shámhat como aquela que infunde saber em Enkídu.

[Verso 204] Variante deste verso: "a meretriz olhou o rosto dele", as duas opções dependendo de que se tenha o objeto do verbo "olhar" determinado por um possessivo no masculino (panišu, "rosto dele") ou no feminino (paniša, "rosto dela"). A opção que adotei, seguindo o texto de GBGE, constitui a lectio difficilior.

[Verso 205] "Escutam seus ouvidos" traduz išema uznašu, em que o último termo, uznu $(m)$, significa tanto "orelha", "ouvido", quanto "entendimento", "sabedoria”.

[Verso 207] Traduzi literalmente [dam]-qa-ta (cf. damquat, de damāqu(m), "estar bom", "ser bom"). Em geral se prefere verter como "és belo".

[Verso 214] O que traduzi por "sagaz" (em mūdu libbašsu, "seu coração sagaz") é o

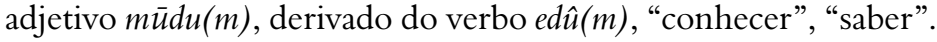


[220] Eu próprio o desafiarei, ----

Gritarei no coração de Úruk: Sou o mais valente!

[222] ---- o destino mudarei:

O na estepe nascido é valente, forte!

[224] Que o povo veja tua face,

---- ele está, possa eu saber!

[226] Vai, Enkídu, a Úruk, o redil,

Onde os jovens cingem uma faixa,

[228] Todo dia ---- acontece um festival

Onde retumbam tambores

[230] E as meretrizes têm elegante forma,

Enfeitadas de encantos, cheias de alegria:

[232] Dos leitos, de noite, saem os idosos!

Enkídu, aquele que não conheceu a vida!,

[234] Mostrar-te-ei Gilgámesh, um homem contente,

Olha para ele, vê sua face,

[236] Pleno de virilidade, dono de poderio,

[Verso 221] Parte da primeira palavra perdeu-se, tendo eu seguido, na tradução, a proposta de reconstituição de PSBEG: [lu-șar]-ri-ih, "gritarei".

[Verso 224] Quem passa a falar a partir daqui é de novo Shámhat. Note-se como a passagem do discurso direto de Enkídu para o da prostituta se fez sem fórmulas ou verbos dicendi, o que produz enfático efeito. Cumpre, todavia, ressaltar que a primeira parte do verso está danificada, o termo "povo" sendo proposto por GBGE, p. 550, para completá-lo ([nišū (̀̀g)meš? ] li-mu-ra pa-ni-ka), havendo contudo outras propostas, como a de Tournay e Shaffer, [lü nillika li-mu]-ra pa-ni-ka, "Eia, vamos, que ele veja teu rosto" (apud SEG, p. 114).

[Verso 227] Os jovens cingem a faixa para a prática da luta como esporte. 
Encorpado de encantos todo o seu corpo,

[238] Mais valentia e força que tu ele tem,

Insone de dia e de noite.

[240] Enkídu, abandona teus vícios,

A Gilgámesh Shámash o ama,

[242] Ánu, Énlil e Ea fizeram plena sua sabedoria:

[Verso 237] O verso é zu-'u-na k[u-u]z-ba ka-luzu-um-ri-šu (literalmente, "cheia de atrativos toda a sua pessoa" ou "o seu corpo"), em que se observa a aliteração em "z" (precedido ou seguido de "u"), o que tentei sugerir com "encorpado... encantos... corpo". O termo kuzbu(m), que traduzi por "encanto", tem a conotação de "apelo sexual", podendo nomear os "genitais femininos" e a "potência sexual" do homem (daí eu ter insistido no termo "corpo").

[Verso 240] O que traduzi por "vício" é šêrtu, "culpa", "crime” e também a "punição"; pode significar ainda uma "ofensa" contra um rei ou um deus. Cf. SEG, p. 114, "parece que o texto sugere a necessidade de [Enkídu] apresentar-se diante de Gilgámesh num estado de pureza ritual, por tratar-se de um ser superior, régio e amado dos deuses".

[Verso 241] Shámash (Šamaš) é o deus Sol (em sumério Utu), sob cuja especial proteção se colocava a primeira dinastia real de Úruk, que pretendia dele descender. De acordo com a lista de reis sumérios, Meski'ang-gasher era filho de Utu, tendo sido o senhor e rei no Eana durante 324 anos; foi sucedido por seu filho Enmerkar, o fundador de Úruk, que reinou 420 anos; sucedeu-o Lugalbanda, o pastor, cujo reinado durou 1.200 anos; em seguida veio Dumuzi, o pescador, que reinou 100 anos; então é a vez de Gilgámesh, filho de um fantasma $\left(l i l_{2}-l a_{2}\right)$, senhor de Kulaba, que reinou 126 anos. A sucessão épica a essa paralela, presente sobretudo nos poemas dedicados a Enmerkar e Gilgámesh, apresenta-se assim: (a) Utu (o Sol) e Ninsumun (a Senhora Vaca Selvagem) geram (b) Enmerkar, o fundador de Úruk, marido de Inana, com a qual gera (c) Lugalbanda, filho de Enmerkar e também marido de Inana, de quem gera (d) Gilgámesh, filho de Lugalbanda, também marido de Inana, o construtor da muralha de Úruk.

Como assevera Woods, Sons of the Sun, p. 80, "a proeminência do deus Sol é um dos poucos temas básicos que dá coesão ao amplamente desconectado e heterogêneo grupo de poemas que toma os feitos legendários da primeira dinastia de Úruk como assunto. O patrocínio do deus Sol aos reis de Úruk nos textos literários é deveras destacável em vista das práticas cultuais no mundo real, pois, havendo escassas evidências de um culto devotado a esse deus em Úruk, apenas eles sugerem que tal divindade era objeto de especial veneração na cidade”. 
Antes que viesses das montanhas,

Gilgámesh, no coração de Úruk, te via em sonhos.

\section{Os sonhos de Gilgámesh}

[245] Levanta-se Gilgámesh, do sonho busca o sentido, diz a sua mãe:

Mãe, um sonho vi esta noite:

[247] Apareceram-me estrelas no céu,

Como rochas de Ánu caíam sobre mim:

[249] Prendi uma, era pesada para mim,

Tentava movê-la, não podia levantá-la;

[251] A terra de Úruk estava em volta dela,

Toda a terra estava reunida em cima dela,

[253] Apertava-se a multidão em face dela,

[Verso 242] Os três deuses referidos são responsáveis pela totalidade do mundo: Ánu pelo Céu; Ea (ou Enki) pelo Apsû, o abismo subterrâneo; e Énlil pela superfície da terra. De acordo com o pensamento babilônico, o universo é constituído por três camadas: a superior, morada de Ánu, assemelha-se a um reservatório que contém as águas do alto, as quais, quando se rompem as comportas, provocam o dilúvio; a camada central, domínio de Énlil, compreende uma parte de terra firme rodeada por todos os lados pelo mar; finalmente, a morada de Ea é constituída pelas águas subterrâneas que alimentam as fontes. Para um detalhamento maior dos níveis superior e inferior, ver Bottéro e Kramer, 1993, p. 70.

[Verso 245] Como se constata no final, é Shámhat quem continua a falar, relatando os sonhos de Gilgámesh. Trata-se, portanto, de uma narrativa enquadrada que recupera um acontecimento anterior.

Ressalte-se que este verso é o primeiro da segunda tabuinha da versão babilônica antiga (OBII), conservada na Tabuinha de Pensilvânia, o que fornece mais indícios de como Sin-léqi-unnínni trabalhou com o material preexistente.

[Verso 248] A expressão kima kişru ša danim aparece no v. 125 acima para caracterizar Enkídu. Aqui parece que está em causa uma chuva de meteoritos. SEG, p. 114, chama a atenção para a semelhança entre as palavras kişru, "rocha", e kezru, "homem com um corte especial de cabelo" do tipo usado por uma prostituta sagrada, termo que designa um jovem que se dedica igualmente à prostituição sagrada. 
Os jovens acumulavam-se em volta dela, [255] Como um bebê, como a um bebê beijavam-lhe os pés,

A ela amei como esposa, por ela me excitei, [257] Peguei-a e deixei-a a teus pés

[Verso 255] Beijar os pés é sinal de respeito (cf. unassaqu šêpižsu, "beijavam seus pés”). Observe-se que a mesma expressão volta a aparecer em duas outras passagens do poema: a) na promessa que, em troca de seu amor, faz Ishtar a Gilgámesh em 6, 15: "o umbral e o trono beijarão teus pés" (sippū arattû linǎšiqu šêpēka); b) nas homenagens fúnebres a Enkídu em 7, 143 e 8, 87, em que Gilgámesh afirma: "os príncipes da terra beijarão teus pés” (malkū ša qaqqari unǎšsaqu šêpēka). Sobre o caráter fúnebre dessa manifestação, inclusive na proposta de Ishtar, ver Abusch, Ishtar's proposal and Gilgamesh's refusal, p. 155-156: num ritual fúnebre neoassírio (K. 164), o cadáver é posto numa cama, uma tocha contendo plantas aromáticas é acesa, queima-se cedro e os pés do morto são beijados (šēpe tanaššiq).

[Verso 256] Referências como as que se encontram neste verso sugerem que a amizade que está por vir entre Gilgámesh e Enkídu envolve relações sexuais, embora isso nunca fique explícito no poema.

A esse respeito, Renger, 1990, p. 77-78, com base na comparação entre Gilgámesh e Enkídu, Davi e Jônatas, Aquiles e Pátroclo, propõe os seguintes traços como característicos de tais pares de amigos: a) trata-se de uma "forte amizade entre duas e não mais que duas pessoas", os dois sendo do sexo masculino e formando "não somente um par, mas um par relativamente isolado: os dois não se juntam jamais a um terceiro, não há rivais, não há outros pares nem relações com mulheres"; b) a relação, "sejam quais forem suas características sentimentais, sempre tem um foco externo (...) na realização de gloriosos feitos ou no cumprimento de finalidades políticas"; c) os pares apresentam uma "assimetria estrutural, que consiste numa distribuição desigual de precedência entre seus membros e num tratamento diferente dos mesmos na narrativa", um deles aparecendo como mais importante que o outro: Aquiles com relação a Pátroclo, Davi em face de Jônatas, Gilgámesh diante de Enkídu.

No último caso, continua o mesmo autor (p. 81), "a afeição de Gilgámesh por seu amigo é descrita em termos apropriados para relações tanto com parentes, quanto com objetos de desejo sexual". Enkídu é comumente chamado de "irmão" (ahu) de Gilgámesh, enquanto o sentimento deste pelo companheiro "é explicitamente modelado em termos de atração sexual" (como no presente caso dos sonhos premonitórios e, após a morte de Enkídu, no modo como Gilgámesh o pranteia como "uma viúva" e vela seu corpo como se fosse "uma noiva"). Conclui-se que 
E tu a uniste comigo.

[259] A mãe de Gilgámesh, inteligente, sábia, tudo sabia e disse a seu filho,

A vaca selvagem Nínsun, inteligente, sábia, tudo sabia e disse a Gilgámesh:

[261] Apareceram-te estrelas no céu,

Como rochas de Ánu caíam sobre ti:

[263] Prendeste uma, era pesada para ti,

Tentavas movê-la, não podias levantá-la;

[265] Pegaste-a e a deixaste a meus pés

E eu a uni contigo:

[267] A ela amaste como uma esposa, por ela te excitaste.

Vem para ti um forte companheiro, amigo salvador,

[269] No país é ele que mais força tem,

Como uma rocha de Ánu é sua poderosa força.

[271] A ele amarás como uma esposa, por ele te excitarás,

Ele, forte, sempre a ti salvará.

[273] É bom, é precioso o teu sonho!

$\left[273^{a}\right]$ Um segundo sonho ele viu. ${ }^{\star}$

Levantou-se e apresentou-se diante da deusa sua mãe, [275] Gilgámesh a ela diz, a sua mãe:

De novo, mãe, vi um segundo sonho:

[277] Numa rua da praça de Úruk ${ }^{\star}$

Um machado estava jogado, diante dele uma reunião,

"a base para essas analogias com parentesco e objetos de desejo sexual parece estar no fato de que a amizade de Enkídu permite a Gilgámesh experimentar um gosto proléptico dos prazeres decorrentes da sociabilidade humana, incluindo casamento e paternidade".

[Verso 273a] Este verso é uma variante do v. 273.

[Verso 277] Trata-se de mais um epíteto de Úruk: urukki rubītu, que GBEG, p. 555, traduz como "Uruk-Main-Street", seguido por SEG, p. 107, "Uruk de la Gran Via". O termo rebìtu/ribitu designa "praça", um "espaço aberto" na cidade, aplicando-se especialmente a Úruk e Acad. Cf. GBEG, p. 183, "'Rua-Principal' é um epíteto que significa que Úruk era famosa por seu ribìtum, a principal via pública da cidade". Outros manuscritos apresentam a lição já conhecida urukki supuri, "Úruk o redil". 
[279] A terra de Úruk estava em volta dele,

Toda a terra estava reunida em cima dele,

[281] Apertava-se a multidão em face dele,

Os jovens acumulavam-se em volta dele,

[283] Peguei-o e deixei-o a teus pés,

A ele amei como uma esposa, por ele me excitei,

E tu o uniste comigo.

[286] A mãe de Gilgámesh, inteligente, sábia, tudo sabia e disse a seu filho,

A vaca selvagem Nínsun, inteligente, sábia, tudo sabia e disse a Gilgámesh:

[288] Filho, o machado que viste é um homem,

A ele amarás como uma esposa, por ele te excitarás,

[290] E eu o unirei contigo.

Vem para ti um forte companheiro, amigo salvador,

[292] No país é ele que mais força tem,

Como uma rocha de Ánu é sua poderosa força.

[294] Gilgámesh a ela diz, a sua mãe:

Mãe, pela boca do conselheiro Énlil tal me aconteça!

[296] Um amigo, um conselheiro eu ganharei,

Ganharei eu um amigo, um conselheiro!

[298] Foi assim que viu seus sonhos.

Depois que Shámhat os sonhos de Gilgámesh contou a Enkídu, [300] Fizeram amor os dois.

[Verso 278] Como anota SEG, p. 115, “o termo que designa 'machado', hașşinnu, é semelhante a assinnu, 'jovem dedicado à prostituição sagrada”".

[Verso 295] Cf. GBGE, p. 803-804, tanto se pode ler o "conselheiro Énlil” (dEnlil māliku) quanto o "príncipe Énlil" (dEnlil maliku/malku). Observe-se que, enquanto $m a \bar{l} l i k u$ (conselheiro), Énlil é o protótipo do príncipe (maliku), no sentido de que toma decisões baseadas em informações judiciosas e corretas. Na concepção babilônica, $\mathrm{o}$ rei é um māliku-amēlu, um "homem-conselheiro", a sua habilidade em dar conselhos acertados estando em relação com a capacidade de exercer o poder. 
[1] Enkídu estava assentado diante dela. ${ }^{\star}$

\section{Referências}

Obras citadas por meio de siglas:

CAD - The Assyrian dictionary of the Oriental Institute of the University of Chicago. Chicago: The Oriental Institute/ Glückstadt: J. J. Augustin Verlagsbuchhandlung, 1956-2010 (21 vols.).

DCA - BLACK, J.; GEORGE, A.; POSTGATE, N. A concise dictionary of Accadian. Wiesbaden: Harrassowitz, 2000.

GBGE - GEORGE, A. R. The Babylonian Gilgamesh Epic. Introduction, critical edition and cuneiform texts. Oxford: Clarendon Press, 2003.

GDS - BLACK, J.; GREEN, A. Gods, demons and symbols of Ancient Mesopotamia. Illustrations by Tessa Rickards. Austin: University of Texas Press, 2003.

PSBEG - PARPOLA, S. The standard Babylonian epic of Gilgamesh. Cuneiform text, transliteration, glossary, indices and sign list (State Archives of Assyria: Cuneiform Texts 1). Helsinki: University of Helsinki, 1997.

SEG - SANMARTÍN, J. Epopeya de Gilgameš, rey de Uruk. Madrid: Trotta/ Barcelona: Publicacions i Edicions de la Universitat de Barcelona, 2010.

SGG -SERRA, O. J. T. A mais antiga epopeia do mundo: a gesta de Gilgamesh. Salvador: Fundação Cultural do Estado da Bahia, 1985.

Outras obras:

ABUSCH, T. Ishtar's proposal and Gilgamesh's refusal: an interpretation of "The Gilgamesh Epic", tablet 6, lines 1-79. History of religions, Chicago, vol. 26, n. 2, p. 143-187, 1986.

ABUSCH, T. The development and meaning of the epic of Gilgamesh: an interpretive essay. Journal of the American Oriental Society, Ann Arbor, vol. 121. n. 4, p. 614-622, 2001.

d'AGOSTINO, F. Gilgameš o la conquista de la imortalidad. Madrid: Trotta, 2007.

BAILEY, J. A. Initiation and the primal woman in Gilgamesh and Genesis 2-3. Journal of biblical literature, Atlanta, vol. 89, n. 2, p. 137-150, 1970.

BOTTÉRO, J., KRAMER, N. S. Lorsque les dieux faisaient l'homme: mythologie

[Verso 1] Esta linha constitui o reclame, ou seja, a chamada para o primeiro verso da segunda tabuinha. Trata-se de um recurso gráfico convencional na apresentação do texto de uma sequência. 
mésopotamienne. Paris: Gallimard, 1993.

DICKSON, K. Looking at the other in Gilgamesh. Journal of the American Oriental Society, Ann Arbor, vol. 127, n. 2, p. 171-182, 2007.

DICKSON, K. The wall of Uruk: iconicities in Gilgamesh. Journal of Ancient Near Eastern Religions, Leiden, vol. 9, n. 1, p. 25-50, 2009.

GEORGE, A. (Translation with an introduction). The Epic of Gilgamesh. London: Penguin Books, 2003.

LAMBERT, W. G. A Catalogue of texts and authors. Journal of Cuneiform Studies, Boston, n. 16, p. 59-77, 1962.

LAMBERT, W. G. Ancestors, authors and canonicity. Journal of Cuneiform Studies, Boston, n. 11, p. 13, 1957.

LERNER, G. The origin of prostitution in Ancient Mesopotamia. Signs: Journal of Women on Culture and Society, New Jersey, vol. 11, n. 2, p. 236-255. 1985.

OPPENHEIM, A. Leo. Mesopotamia: portrait of a dead civilization. Chicago: University of Chicago Press, 1977.

RENGER, J. M. Heroes and their pals. In: HALPERIN, D. M. (org.). One hundred years of homosexuality and others essays on Greek love. New York: Routledge, 1990, p. 75-87.

SASSON, J. M. The composition of the Gilgamesh epic. Studies in Philology, Chapel Hill, vol. 69, n. 3, p. 259-279, 1972.

SILVA CASTILLO, J. Iśdi mati, The foundations of the Earth. Journal of the American Oriental Society, Ann Arbor, vol. 121, n. 1, p. 93-94, 2001.

SILVA CASTILLO, J. La estructura literaria como guía para la traducción: el primer verso de "Gilgamesh". Estudios de Asia y África, México, vol. 35, n. 1, p. 11-27, 2000. SILVA CASTILLO, J. "Nagbu": totality or abyss in the first verse of "Gilgamesh". Iraq, London, vol. 60, p. 219-221, 1998.

SPAR, I., LAMBERT, W. G. Cuneiform texts of the Metropolitan Museum of Arts. vol. 2. New York: Metropolitan Museum of Arts, 2005.

WOODS, C. Sons of the Sun: the mythological foundations of the first dynasty of Uruk. Journal of Ancient Near Eastern Religions, Leiden, vol. 12, p. 78-96, 2012.

WORTHINGTON, M. On names and artistic unity in the standard version of the Babylonian Gilgamesh epic. Journal of the Royal Asiatic Society, London, vol. 21, n. 4, p. 403-420, 2011. 
